\title{
LinkedIn job offers aimed at advertising graduates in Spain
}

\author{
Jorge Clemente-Mediavilla; Rebeca Antolín-Prieto
}

Nota: Este artículo se puede leer en español en:

http://www.elprofesionaldelainformacion.com/contenidos/2019/nov/clemente-antolin_es.pdf

How to quote this article:

Clemente-Mediavilla, Jorge; Antolín-Prieto, Rebeca (2019). "LinkedIn job offers aimed at Advertising graduates in Spain". El profesional de la información, v. 28, n. 6, e280613.

https://doi.org/10.3145/epi.2019.nov.13

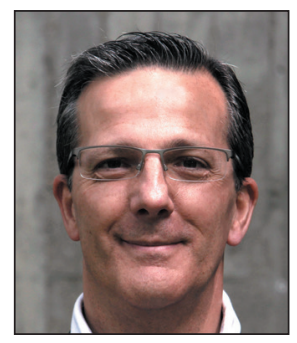

Jorge Clemente-Mediavilla $₫$ https://orcid.org/0000-0002-9819-1129

Universidad Complutense de Madrid Facultad de Ciencias de la Información Avda. Complutense, 3 28040 Madrid, Spain jclemen@ucm.es

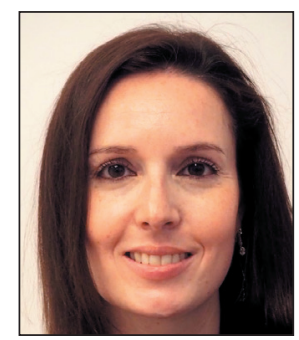

Manuscript received on $31^{\text {th }}$ March 2019 Accepted on $23^{\text {th }}$ August 2019

\begin{abstract}
This research analyzes the profiles and professional skills required from graduates in Advertising in Spain by companies and recruiters. We carried out a content analysis of the job offers addressed to graduates in Advertising published in January 2019 in Spain on the digital platform LinkedIn. The offers information was systematized in categories related to descriptive data (type of contract, data on required skills, etc.). The analysis of the results reveals a certain degree of confusion on the part of the companies when it comes to establishing the limits between the profile and professional skills of a graduate in Advertising and those of graduates in Fine Arts, Marketing and Business Administration. The analysis has also confirmed the significant changes that the digital age has generated in the profiles and professional skills described in higher education with respect to those currently in demand in the labor market.
\end{abstract}

\section{Keywords}

Advertising; Professional skills; Professional profiles; Job; Job offers; LinkedIn; Academy; University education; Spain.

\section{State of the question}

Education in the field of Advertising in Spain started in 1925 with a master class by Pedro Prat Gaballí in Barcelona (Méndiz-Noguero, 2000). This would be only the beginning of a series of lessons which gradually made an impression on the professionals of the day and became the seed of the first official institution which, decades later, would specialize in teaching Advertising, the Escuela Oficial de Publicidad [Official Advertising School], founded in 1964. In 1971, the official Advertising, Journalism, Cinema and Television schools acquired university status, which led to the opening of a Faculty of Information Science at the Universidad Complutense de Madrid (UCM) and one at the Universitat Autònoma de Barcelona (UAB).

Right from the start, through the early 1970s, the curriculum was approached in different ways in these two universities; the UCM opted for a closed structure with no electives while the UAB gave students freedom to take electives through four of the five years of the degree course (Méndiz-Noguero, 2000).

Almost fifty years have gone by and the digital age has undeniably changed the labour market as well as the required professional profiles and skills, a fact that is confirmed through a search on the Linkedln online platform. Therefore, scholars should address the balance between Advertising graduates' skills and the type of profile and professional skills that will be required from students through their future working life.

This study proposes, first, a specification of the professional skills and profiles required by companies in their job offers targeted to Advertising graduates in Spain through an analysis of this type of offers on Linkedln. Second, we intend to 
provide an account of the differences existing between these and those taught in higher education, based on those set out by the Agencia Nacional de Evaluación de la Calidad y Acreditación (Aneca) [National Agency for Quality Assessment and Accreditation of Spain] in 2005 in its Libro blanco de los títulos de grado en comunicación [Book on university communication degrees], specifically in relation to Advertising degrees.

To this aim, we have reviewed the scientific literature that relates higher education to the digital economy framework so as to have a current panorama of its impact on skills development in education (Rychen; Tiana-Ferrer, 2004; Karpati, 2011), and more specifically, on Spanish university degrees (Ministerio de Energía, Industria y Turismo, 2015), as well as how these skills are reflected in new jobs (European Commission, 2010).

The development of digital skills in higher education (Arias-Oliva; Torres-Coronas; Yáñez-Luna, 2014; Alonso-Benito; Fernández-Rodríguez; Nyssen-González, 2009) is the current subject of many academic debates, and is also subject to criticism on account of a lack of technological skills in academia (Álvarez-Flores; Núñez-Gómez; Rodríguez-Crespo, 2017). Thus, it is necessary to understand the way Information and Communication Technologies (ICT) have been integrated in Communication degree courses (Flores-Vivar; Martínez-Gutiérrez; Cabezuelo-Lorenzo, 2012), and also the adaptation process to the European Higher Education Area (EHEA) in Communication teaching (Marta-Lazo; Vadillo-Bengoa, 2013; Rodrigo-Alsina; Lazcano-Peña, 2014), and the origins and challenges that Advertising education and training has had to face in Spain (Méndiz-Noguero, 2000). To this aim, we have analyzed scientific papers on the subject of cross-functional skills for Communication and Information in the Digital Society (Marta-Lazo; Agustín-Lacruz; Ubieto-Artur, 2012), and the skills necessary for $21^{\text {st }}$ century digital communicators (Perlado-Lamo-de-Espinosa, 2013; Bravo; Madinaveitia, 2015).

According to the statements in the Libro blanco, the Advertising degree includes four professional profiles (Aneca, 2005):

- communication director, researcher and strategic consultant in advertising and public relations

- media researcher, planner and buyer

- creative executive and designer

- corporate communications manager.

Furthermore, up to twelve professional skills are listed, which are assessed through a 1-4 score, namely skills and abilities to:

- use communicative technologies and techniques

- practice and teach the profession

- establish fluent and competent interaction between advertisers and agencies

- schedule a communication plan

- draw up and manage communication budgets for correct cost allocation

- identify, assess, manage and protect a company's intangible assets

- be in charge of an agency's customer service

- be in charge of the communication area of institutions or companies

- work as experts in strategic management of a company's corporate image

- work in the media department

- write creative copy

- create and develop graphics.

According to this data, the most valued skills would be the skill and ability to:

- use communicative technologies and techniques

- practice and teach the profession

- establish fluent and competent interaction between advertisers and agencies

- create and develop graphics.

Previous studies on the emerging professional profiles in the digital economy environment related to Communication Science studies (Vivar-Zurita et al., 2010; Marta-Lazo; Agustín-Lacruz; Ubieto-Artur, 2012; Flores-Vivar, 2013) analyze online communication industries, a new paradigm (Serrano-Cobos, 2016), and new job opportunities related to digital contents (Telos, 2015; FTI; Ametic, 2013), and they also introduce the "community manager" (Baladrón-Pazos, 2010) and focus on the transformation that journalism has gone through by relating the job offers on the Internet to the Aneca's Libro blanco (Marta-Lazo; González-Aldea; Herrero-Curiel, 2018).

In direct relation to the object of study in this digital economy environment, the scientific literature reviewed analyzes the new professional profiles in demand in relation to training and education and their opportunities in this new labour market (Corredor-Lanas; Farfán-Montero, 2010; Corredor-Lanas, 2011; IAB Spain, 2011; Núñez-Gómez; García-García; Abuín-Vences, 2013; Perlado-Lamo-de-Espinosa, 2013); one study addresses hybridization in these job opportunities (Álvarez-Flores; Núñez-Gómez; Olivares-Santamarina, 2018), while other authors focus on the creative executive profile (Perlado-Lamo-de-Espinosa; Rubio-Romero, 2015) and on the role of media planners in the digital area (Perlado-Lamo-de-Espinosa; Papí-Gálvez; Bergaz-Portolés, 2019), as well as on the operation of advertising agencies in digital culture (Del-Río-Pérez; Kaufmann, 2011), and the challenge this entails (Telos, 2015). 
The main objective of this study was to identify those Advertising ${ }^{1}$ professional profiles and skills which are most required by companies.

Other objectives of this study include:

- To ascertain current companies' requirements for Advertising graduates to enter the market labour

- To find out the type of contracts offered to Advertising professionals in available job opportunities.

- To compare the professional skills described in the Libro blanco for the Advertising degree to those currently in demand in the labour market.

\section{Method}

We carried out a review of the scientific papers with references to our object of study by applying the content analysis technique (Bardin, 1996). 428 job offers addressed to Advertising graduates posted on the specialized social network LinkedIn were analyzed, given that it is the most used job search tool in Spain both by applicants and recruiters. Taking into account the way LinkedIn works and its search results, we created a list of categories for subsequent data analysis and presentation of results.

The timeframe -January 2019- selected to build the sample was chosen because this is a period when a large number of contracts are traditionally signed. The bulk of companies do their annual budget before January to identify those professionals who will continue working in their positions and those who will not. The highest number of offers is generally concentrated in the second half of the month, both for temporary and permanent jobs. This makes it a representative and appropriate time framework to carry out the field work.

With regard to LinkedIn, the platform selected for data collection, it is a professional social network which has been operational since 2003; it has over 575 million of users across the world, $40 \%$ of whom (260 million active users) use it on a daily basis. The main reason users are active on the platform is recruitment effort; with more than 20 million companies publishing offers and over 14 million open jobs, it is no wonder that $90 \%$ of recruiters are regular users. As to the geographical context of interest -Spain- this social network has been in use since 2012 and has more than 10 million users. This means that over fifty per cent of working professionals are using it, which makes it one of the main transformation agents in the Spanish working world. Furthermore, this social network provides access to 9 million companies and has more than 100,000 articles posted per week. It suffices to point out that the bulk of business in Spain is mainly made up of SMEs and entrepreneurs with innovative projects, an environment which perfectly matches LinkedIn's vision and mission. In Spain, over fifty per cent of recruiters use social networks to spot and hire talent (Puromarketing, 2018), so much so that they turn down applicants with no LinkedIn profile, which reveals a high degree of evolu-

In Spain, over fifty per cent of recruiters use social networks to spot and hire talent, and they turn down applicants with no LinkedIn profile tion in relation to traditional job searching.

The total number of offers collected requiring an Advertising degree as a criterion amounted to 428 , of which, in a deeper sub-division of functions,

139 included both Advertising and Sales,

130 Advertising and Marketing,

94 Advertising and Design,

47 Advertising and Business Development, and

18 Advertising on its own.

Therefore, it is not surprising that Advertising graduates find themselves competing for these jobs with Business Administration and Management, Marketing, and Fine Arts (Design) graduates, and that job postings feature job titles such as Advertiser, Digital Marketing Specialist, Community Manager, Marketing Communications, Graphic Designer, Art Manager, Digital Media Planner, Commercial Director and Project Manager, etc.

Given that the analysis is focused on job offers addressed at Advertising graduates, the minimum required level of studies was grouped under three categories differentiating the Advertising graduate offers from those that also included other degrees such as Marketing, Business Administration, and Fine Arts.

It is worth noting that the job titles in offers requiring an Advertising degree were written in English and the job description was also in English or demanded a C1 level (Advanced) command of this language. In order to carry out the content analysis, we established various categories within the skills and profiles required by companies in the Advertising field. Thus, we divided the data offered and required in job offers as set out in Table 1.
Table 1. Professional profiles and skills of Advertising graduates in Spain according to the offers by companies and recruiters on LinkedIn

\begin{tabular}{|l|l|}
\hline \multicolumn{1}{|c|}{ Required profiles } & \multicolumn{1}{c|}{ Professional skills } \\
\hline & 1. Job duties \\
1. Minimum education level & 2. Knowledge of office functions \\
2. Minimum experience & 3. Knowledge of editing software \\
3. Area of work & 4. Knowledge of social networks \\
4. Profiles required & 5. Knowledge of online metrics \\
& 6. Languages \\
\hline
\end{tabular}


Out of the twelve skills included in the Libro blanco (Aneca, 2005), we selected those which were featured most often in Linkedln job offers descriptions (job duties, knowledge of office functions, knowledge of editing software, of social networks, metrics, and languages), which were grouped as shown in Table 2.

Table 2. Professional skills according to companies in relation to academic professional skills

\begin{tabular}{|c|c|}
\hline Professional skills according to companies & Academic professional skills \\
\hline \multirow{5}{*}{ I. Job duties } & 1. Capacity and ability to be in charge of the communication area of institutions or companies \\
\hline & 2. Capacity and ability to identify, assess, manage and protect a company's intangible assets \\
\hline & 3. Capacity and ability to practice and teach the profession \\
\hline & $\begin{array}{l}\text { 4. Relational and enquiry capacity to establish fluent and competent interaction between } \\
\text { advertisers and agencies }\end{array}$ \\
\hline & 5. Capacity and ability to be in charge of an agency's customer service \\
\hline II. Knowledge of office functions & 1. Capacity to define and manage communication budgets for correct cost allocation \\
\hline \multirow{3}{*}{ III. Knowledge of editing software } & 1. Capacity and ability to write creative copy \\
\hline & 2. Capacity and ability to create and develop graphic elements \\
\hline & $\begin{array}{l}\text { 3. Capacity and ability to work as experts in strategic management of a company's corporate } \\
\text { image }\end{array}$ \\
\hline IV. Knowledge of social networks & 1. Capacity and ability to use communicative technologies and techniques \\
\hline \multirow{2}{*}{ V. Knowledge of online metrics } & 1. Capacity and ability to work in the media department \\
\hline & 2. Capacity and ability to schedule a communication plan \\
\hline VI. Languages & 1. No skill related to this point \\
\hline
\end{tabular}

\section{Analysis and results}

The jobs segmented by duties or areas described in offers addressed to Advertising graduates are presented in Table 3 and the experience level required can be seen in Table 4.

Furthermore, as noted in some of the studies presented in the state of the question section -which noted a potential change in job denomination-, this is indeed reflected in the jobs titles in the offers published. Thus, we find new profiles for Advertising graduates such as:

- Digital media planner (15\%),

- Digital marketing specialist (35\%),

- Community manager (5\%),

- Digital marketing communications (19\%),

- UX designer (5\%),

- Digital account executive (10\%),

- Digital brand manager (5\%), and

- Visual content creator (3\%), among others.

Table 3. Duties or areas described in offers

\begin{tabular}{|l|c|}
\hline \multicolumn{1}{|c|}{ Duties or areas } & \% jobs \\
\hline Sales & 32 \\
\hline Marketing & 30 \\
\hline Design & 22 \\
\hline Business development & 11 \\
\hline Inherent to Advertising & 4 \\
\hline
\end{tabular}

Table 4. Experience required

\begin{tabular}{|l|c|}
\hline \multicolumn{1}{|c|}{ Experience } & \% jobs \\
\hline Students (internships) & 5 \\
\hline Graduates (entry level) & 64 \\
\hline Graduates with 2-3 years of experience (associates) & 23 \\
\hline Graduates with 4-6 years of experience (mid-level senior) & 6 \\
\hline Graduates with 8-10 years of experience (director) & 2 \\
\hline Graduates with more than 10 years of experience (executive) & 1 \\
\hline
\end{tabular}

In addition to this, traditional profiles which do not include the term "digital" in the job title tend to be high management levels positions.

Table 5 shows the correspondence between the four academic professional profiles in the Libro blanco (Aneca, 2005) and the job offers published by companies and recruiters on LinkedIn, which shows there actually have been significant changes which should be taken into account to update the Advertising Degree curriculum.

The five academic professional skills included which explicitly appear in the job duties of the 428 job offers analyzed are the following:

- Relational and enquiry capacity to establish fluent and competent interaction between advertisers and agencies (15\%)

- Capacity to identify and manage communication budgets for correct cost allocation (20\%)

- Capacity and ability to write creative copy; capacity and ability to work as experts in the strategic management of a company's corporate image (15\%)

- Capacity and ability to use communicative technologies and techniques (20\%)

- Capacity and ability to work in the media department (15\%). 
Table 5. Relationship between the professional profiles as described in higher education and the job offers published by companies and recruiters on Linkedln

\begin{tabular}{|c|c|}
\hline Professional profiles published in higher education & Job offers on Linkedln \\
\hline \multirow{8}{*}{$\begin{array}{l}\text { I. Communication director, researcher and strategic consultant in advertising } \\
\text { and public relations }\end{array}$} & 1. Digital account executive \\
\hline & 2. Digital marketing specialist \\
\hline & 3. Account executive \\
\hline & 4. Marketing manager \\
\hline & 5. Campaign manager \\
\hline & 6. Global business development \\
\hline & 7. Commercial director \\
\hline & 8. Project manager \\
\hline \multirow{3}{*}{ II. Media researcher, planner and buyer } & 1. Digital media planner \\
\hline & 2. Media planner associate \\
\hline & 3. Integrated media director \\
\hline \multirow{6}{*}{ III. Advertising creative executive and designer } & 1. UX designer \\
\hline & 2. Visual content creator \\
\hline & 3. Graphic designer \\
\hline & 4. Art director \\
\hline & 5. Copy writer \\
\hline & 6. Digital creative director \\
\hline \multirow{5}{*}{ IV. Corporate communication manager } & 1. Digital brand manager \\
\hline & 2. Community manager \\
\hline & 3. Digital marketing communications \\
\hline & 4. Brand manager assistant \\
\hline & 5. Global brand director \\
\hline
\end{tabular}

Knowledge of office functions does not generally appear in job offers, though there is a two-track differentiation between

- offers addressed to creative profiles and which require mastery of Adobe tools and social network management, and

- offers addressed to executive/strategic planner profiles, which require mastery of measurement tools (AdWords management) and deep knowledge of the digital scene.

In terms of knowledge of languages, most job offers feature a Spanish-English bilingual component: $65 \%$ of job descriptions are fully written in English rather than Spanish, and most job offers are also published in English (even when the actual job will be carried out in Spanish, 35\%). Furthermore, 65\% of job offers require C1 written and spoken English (advanced), 25\% require B2 English, 5\% describe that the job requires English language knowledge without specifying level, and $5 \%$ of offers require fully bilingual applicants.

An analysis of the results of the professional skills required by companies -following the higher education model for Advertising degrees- reveals that only six of the twelve skills described in the Libro blanco are featured on Linkedln job offers, namely:

- Relational and enquiry capacity to establish fluent and competent interaction between advertisers and agencies

- Capacity to define and manage communication budgets for correct cost allocation

- Capacity and ability to write creative copy

- Capacity and ability to work as experts in strategic management of a company's corporate image

- Capacity and ability to use communicative technologies and techniques

- Capacity and ability to work in the media department.

However, advanced knowledge of English is not included in the Libro blanco as one of the professional skills currently required from Advertising graduates in the working world. It is also worth noting that the arrival of the Internet has brought with it a series of changes in terms of measurement tools, strategic planning, account management, and, in short, in communication management in the context of an increasingly global and changing market which operates in real time. In this regard, the Libro blanco (Aneca, 2005) falls far short of the current market demands in relation to Advertising graduates.

\section{Discussion and conclusions}

The conclusions in this study are in line with previous research on Advertising graduate profiles in the age of the Web 2.0, and confirm a need of more frequent studies in this field in view of the dramatic changes in the digital environment.

It is worth highlighting that companies increasingly require in their job offers professional skills such as capacity to team work, leadership skills, capacity to work in international and intercultural environments, ability to work under pressure, proactivity, passion for technology, etc. 
This new working scenario reveals that job offers for Advertising graduates generally include direct competition with Business Administration, Marketing, and Fine Arts graduates. Therefore, universities should carry out a revision of the Advertising Degree curricula so that they meet the demands of new job requirements. Furthermore, the study confirms that companies are not actually familiar with the professional skills of Advertising graduates.

Thus, the analysis of the information data leads us to conclude that the irruption of a new environment has created a gap between the academic education of university Advertising students and companies' requirements in the Advertising job offers analyzed given that academic professional skills match the skills currently required from Advertising graduates in the Spanish labour market only to a level of 50\%. This reveals that synergies and dialogue between the business world and universities are ever more necessary. Companies are currently searching for applicants whose skills and profiles are not featured in the Libro blanco, which means that it is vital that the contents and subjects included in the Advertising Degree curriculum are revised so that future graduates are qualified and can compete in a labor market that is ever changing, multidisciplinary, and global.

\section{Notes}

1. Although in Spain university degrees includes in many cases a Public Relations heading, this study has exclusively focused on Advertising.

2. LinkedIn has become a solid and essential tool for talent searchers, it is therefore an essential site for job searchers. The data shared in the link below supports and expands this information https://www.puromarketing.com/16/30295/LinkedIn-cumple-anos-mas-millones-usuarios.html

\section{References}

Alonso-Benito, Luis-Enrique; Fernández-Rodríguez, Carlos J.; Nyssen-González, José-María (2009). El debate sobre las competencias. Una investigación cualitativa en torno a la educación superior y el mercado de trabajo en España. Madrid: Aneca. ISBN: 9788469173947

Álvarez-Flores, Erika-Patricia; Núñez-Gómez, Patricia; Rodríguez-Crespo, Carlos (2017). “Adquisición y carencia académica de competencias tecnológicas ante una economía digital”. Revista latina de comunicación social, n. 72, pp. 540-559. https://doi.org/10.4185/rlcs-2017-1178

Álvarez-Flores, Erika-Patricia; Núñez-Gómez, Patricia; Olivares-Santamarina, José-Pedro (2018). “Perfiles profesionales y salidas laborales para graduados en Publicidad y Relaciones públicas: de la especialización a la hibridación”. EI profesional de la información, v. 27, n. 1, pp. 136-147.

https://doi.org/10.3145/epi.2018.ene.13

Aneca (2005). Libro blanco. Títulos de grado en Comunicación. Madrid: Agencia Nacional de Evaluación de la Calidad y Acreditación.

http://www.aneca.es/var/media/150336/libroblanco_comunicacion_def.pdf

Arias-Oliva, Mario; Torres-Coronas, Teresa; Yáñez-Luna, Juan-Carlos (2014). “El desarrollo de competencias digitales en la educación superior". Historia y comunicación social, v. 19, pp. 355-366.

https://doi.org/10.5209/rev_hics.2014.v19.44963

Baladrón-Pazos, Antonio (2010). "La docencia en Comunicación en el EEES ante los perfiles profesionales emergentes: el caso de los community managers”. En: Sierra-Sánchez, Javier; Cabezuelo-Lorenzo, Francisco (coords.). Competencias y perfiles profesionales en los estudios de Ciencias de la Comunicación. Madrid: Fragua, pp. 206-219. ISBN: 9788470743986

Bardin, Laurence (1996). Análisis de contenido. Madrid: Akal. ISBN: 8476000936

Bravo, Julián; Madinaveitia, Eduardo (2015). "La publicidad en 2014: transformaciones ante el reto digital”. Telos, n. 99, pp. 56-63.

https://telos.fundaciontelefonica.com/archivo/numero099

Corredor-Lanas, Patricia (2011). “En clave digital. Nuevos profesionales en publicidad”. Telos, n. 87, pp. 97-100. https://telos.fundaciontelefonica.com/archivo/numero087

Corredor-Lanas, Patricia; Farfán-Montero, Juana (2010). “Demandas y formación: Nuevos perfiles profesionales para la publicidad en España”. Pensar la publicidad: revista internacional de investigaciones publicitarias, v. 4, n. 1, pp. 97-116. https://revistas.ucm.es/index.php/PEPU/article/view/PEPU1010120097A

Del-Río-Pérez, Jorge; Kaufmann, Jürg (2011). "Revisión teórica de la agencia publicitaria en la cultura digital”. adComunica, n. 8, pp. 57-71.

https://doi.org/10.6035/2174-0992.2014.8.5

European Commission (2010). New skills for new jobs: Action now. Brussels: European Union.

https://ec.europa.eu/social/BlobServlet?docld=4508 
Flores-Vivar, Jesús-Miguel (2013). “Perfiles emergentes en la industria de la comunicación online”. En: Agustín-Lacruz, María-del-Carmen; Marta-Lazo, Carmen; Ubieto-Artur, María-Isabel (coords.). Perfiles profesionales y espacios de empleo en información y comunicación. Madrid: Icono 14, pp. 31-51. ISBN: 9788415816027

Flores-Vivar, Jesús-Miguel; Martínez-Gutiérrez, Fátima; Cabezuelo-Lorenzo, Francisco (2012). "El conocimiento integrado de las TIC en las facultades de comunicación". Cuadernos artesanos de latina, n. 25, pp. 137-162. http://www.cuadernosartesanos.org/067/cuadernos/25_Viejo\%20periodismo.pdf

FTI; Ametic (2013). Informe sobre los perfiles profesionales más demandados en el ámbito de los contenidos digitales 2012-2017. Madrid: Fundación de Tecnologías de la Información (FTI) y Asociación de Empresas de Electrónica, Tecnologías de la Información, Telecomunicaciones y Contenidos Digitales (Ametic).

http://ametic.es/es/publicaciones/pafet-vii-perfiles-profesionales-m\%C3\%A1s-demandados-en-el-\%C3\%A1mbito-de-los-contenidos IAB Spain (2011). Informe sobre el mercado laboral del marketing digital. 2a Oleada.

Karpati, Andrea (2011). Digital literacy in education. Policy brief. Unesco: Institute for Information Technologies in Education. https://unesdoc.unesco.org/ark:/48223/pf0000214485

Marta-Lazo, Carmen; Agustín-Lacruz, María-del-Carmen; Ubieto-Artur, María-Isabel (coords.) (2012). Competencias interdisciplinares para la comunicación y la información en la sociedad digital. Madrid: Icono 14. ISBN: 9788493907785

Marta-Lazo, Carmen; González-Aldea, Patricia; Herrero-Curiel, Eva (2018). "Professional skills and profiles in journalism demanded by companies: Analysis of offers at LinkedIn and Infojobs". Communication \& society, v. 31, n. 4, pp. $211-228$. https://www.unav.edu/publicaciones/revistas/index.php/communication-and-society/article/view/35682

Marta-Lazo, Carmen; Vadillo-Bengoa, Nerea (coords.) (2013). Evaluación de la implantación del EEES en los estudios de comunicación. Tenerife: Cuadernos Artesanos de Latina. ISBN: 9788415698135

Méndiz-Noguero, Alfonso (2000). "Origins, evolution and challenges of Advertising education in Spain”. Communication \& society, v. 13, n. 2, pp. 181-225.

https://www.unav.edu/publicaciones/revistas/index.php/communication-and-society/article/view/36388

Ministerio de Industria, Energía y Turismo (2015). Libro blanco para el diseño de las titulaciones universitarias en el marco de la economía digital. Madrid: Ministerio de Industria, Energía y Turismo.

http://www.ccii.es/images/ccii/recursos/Libro-Blanco.pdf

Núñez-Gómez, Patricia; García-García, Alberto; Abuín-Vences, Natalia (2013). “Profesionales digitales en publicidad y comunicación. Una aproximación a las necesidades del mercado laboral”. Cuadernos de información y comunicación, n. 18, pp. $177-187$. https://www.redalyc.org/articulo.oa?id=93528051014

Perlado-Lamo-de-Espinosa, Marta (2013). “Nuevas oportunidades en la comunicación digital: nuevos perfiles y competencias". En: Prospectivas y tendencias para la comunicación en el siglo XXI, pp. 429-440. ISBN: 9788415949176

Perlado-Lamo-de-Espinosa, Marta; Papí-Gálvez, Natalia; Bergaz-Portolés, María (2013). “Del planificador de medios al experto en medios: El efecto digital en la publicidad". Comunicar, v. 27, n. 59.

https://doi.org/10.3916/C59-2019-10

Perlado-Lamo-de-Espinosa, Marta; Rubio-Romero, Juana (2015). “Competencias, habilidades y formación del creativo publicitario en la era digital". Creatividad y sociedad, n. 23, p. 6-34.

https://bit.ly/2HcMEPc

Puromarketing (2018). "Linkedln cumple 15 años con más de 562 millones de usuarios". Puromarketing, 3 mayo. https://www.puromarketing.com/16/30295/linkedin-cumple-anos-mas-millones-usuarios.html

Rodrigo-Alsina, Miquel; Lazcano-Peña, Daniela (2014). “La enseñanza en Comunicación y su proceso de adaptación al EEES como objeto de estudio: una visión panorámica”. Communication \& society, v. 27, n. 2, pp. 221-239.

https://www.unav.edu/publicaciones/revistas/index.php/communication-and-society/article/view/35993

Rychen, Dominique-Simone; Tiana-Ferrer, Alejandro (2004). Developing key competencies in education: Some lessons from international experience. Paris: Unesco. ISBN: 9789231039454

Serrano-Cobos, Jorge (2016). "Tendencias tecnológicas en internet: hacia un cambio de paradigma". El profesional de la información, v. 25, n. 6, pp. 843-850.

https://doi.org/10.3145/epi.2016.nov.01

Telos (2015). La publicidad ante el reto digital, n. 99.

https://telos.fundaciontelefonica.com/archivo/numero099

Vivar-Zurita, Hipólito; Abuín-Vences, Natalia; García-García, Raquel; Vinader-Segura, Raquel; Núñez-Gómez, Patricia (2010). "La transición al EEES: la especificidad como vía para incrementar la tasa de inserción laboral de los titulados en Comunicación”. En: Sierra-Sánchez, Javier; Cabezuelo-Lorenzo, Francisco (coords.). Competencias y perfiles profesionales en los estudios de Ciencias de la Comunicación. Madrid: Fragua, pp. 27-43. ISBN: 9788470743986 